\title{
Does context matter? Voluntary work in long-term care
}

\section{Laila Tingvold ${ }^{*}$}

Centre for Care Research

Norwegian University of Science and Technology (NTNU), Norway

Email: laila.tingvold@ntnu.no

${ }^{*}$ corresponding author

\section{Oddvar Førland}

Centre for Care Research, Western Norway

Western Norway University of Applied Sciences

Email: oddvar.forland@hvl.no

\begin{abstract}
Introduction: Increased voluntary work in long-term care (LTC) is encouraged in white papers in Norway as well as in many other western states. This is due to the growth in the number of service recipients and a subsequent economic burden for the state. Voluntary work in nursing homes and home care services take place in different spatial contexts, but little attention has been paid to how the different contexts may potentially influence the possibilities for voluntary work. The aim of this study is to obtain new knowledge of the significance of context in recruitment of volunteers in LTC.
\end{abstract}

Method: A cross-sectional study was conducted among leaders in nursing homes and home services in 50 municipalities across all regions of Norway. Descriptive analysis was used.

Results: According to the leaders, home care services had less voluntary work than nursing homes. Respondents from home care scored "poor flow of information" and "low interest in the municipality" as major hinderances, more so than respondents from nursing homes did.

Discussion: Nursing homes typically have many residents under one roof following a similar schedule. Thus, volunteer-run activities are held more easily at set times and incorporated into the daily life of the institutions. On the 
other hand, home dwellers in home care stay in a more individualised setting with more autonomy and can opt out of activities that nursing home residents would normally join. Skill acquisition, networking and socializing are common motivations for volunteering, and a nursing home setting may be an easier context to obtain this. The governmental endeavour for increased voluntary work in LTC can be seen as an effort to meet expected rises in public expenditure. However, the realism can be debated due to substantial challenges on the future potential of volunteerism in LTC, especially in the home care context.

Keywords: Voluntary work, volunteers, nursing homes, home care, long-term care, ageing-in-place

\section{Introduction}

In Norway, a call for volunteers to contribute to long-term care (LTC) services has been repeatedly made in recent decades. Official policy documents and white papers state that new forms of cooperation between public and private sectors must be sought (Ministry of Health and Care Services, 2013, p. 11; Ministry of Health and Care Services, 2006, p. 41; Ministry of Health and Care Services, 2017, p. 61; Ministry of Health and Care Services, 2015, p. 47). Similar requests are put forward internationally and reflect an overall concern with the ageing of the population, a growth in demand and expenses for care services and a future deficit of health staff (Groenou \& De Boer, 2016; Hussein \& Manthorpe, 2005).

Despite the fact that the general participation in voluntary organisations in Norway is high (Folkestad et al., 2015; Jegermalm et al., 2019), a study showed that voluntary work in the LTC sector is relatively modest (Andfossen, 2016). This might indicate a discrepancy in expectations between the present strong call for the contribution of volunteers and a relatively stable low prevalence in LTC. Several important issues seem to be overlooked in official documents. One such issue concerns which tasks and types of activities volunteers are supposed to carry out in LTC. However, white paper no. 25 (2005-2006) specifies the importance of enhancing the quality of care by increasing volunteer social and cultural activities in nursing homes and home care services (Ministry of Health and Care Services, 2006; Ministry of Health and Care Services, 2018). Yet, two issues that remain largely undebated 
concern the recruitment of volunteers and the coordination of their effort along with the staff in municipal care services. How is the bringing in of volunteers to be organised in a field with professional care workers? Studies so far indicate that voluntary work in LTC is offered and organised differently in municipalities (Rønning, 2011a; Solbjør et al., 2014; Andfossen 2020) or between organisations (Greenfield et al., 2016). For example, a survey of recruitment and follow-up of LTC volunteers in Norway found that less than half of the 429 municipalities had any organised activity in recruiting new volunteers in the care sector (Johansen \& Lofthus, 2011). A survey mapping voluntary work for the elderly in Oslo also showed variations in how districts recruited volunteers (Romsaas, 2011). Districts that actively developed a culture for cooperation with volunteers reported more contact and communication between volunteers and service suppliers at all levels (Romsaas, 2011). Furthermore, the division of tasks between professional care, volunteers and informal carers appears somewhat blurred and causes coordination challenges (Tingvold \& Skinner, 2019; Skinner et al., 2020; Fredriksen et al, 2020); systems of cooperation are put into operation in a multitude of ways (Hoad, 2002), triggering questions on the best volunteer management in differentiated settings (la Cour, 2019; Hager \& Brudney 2015). Lack of procedures to inform LTC service recipients about the availability of volunteers had also been found (Luijkx \& Schols, 2018), as well as a lack of routines for sharing information between professional carers and volunteers (Fensli et al., 2012a; Ingebretsen, 2005). These studies show that introducing volunteers into LTC services might be a more complicated task than suggested by various governments. It is particularly expected that more difficulties could arise in introducing and running activities by volunteers in nursing homes, as these institutions are formalised in the domain of professional care workers and access is more regulated and restricted. Further, it may be expected that the proportion of individual volunteers to care recipients are higher in private homes due to easier access to neighbours, friends and others in the local community.

Given these facts, little attention has been given to the study of voluntary work in the context of location (i.e., in home care or nursing homes) despite the fact that they are structures governed by different approaches and different models for care. Thus, the focus of this paper is to address the following research question: what types and amounts of voluntary work are found in nursing homes and home care sectors in a selection of Norwegian municipalities? What factors are seen as hindrances to voluntary work among managers of 
nursing homes and managers of home care services and how can these differences be understood?

For this study, "voluntary work" is defined as the unpaid contributions that are given without reward or compensation that benefit individuals or groups outside family and close friends (Førland, 2015; Snyder \& Omoto, 2008). Individual unpaid work carried out by volunteers through voluntary organisations and volunteer centrals is also included, as well as work done by those who do voluntary, unpaid work independently of formal organisations. Unpaid work, informal care or help given to members of one's family, friends or neighbours is not defined as voluntary work in this study. The term "service recipients" in this research denotes persons receiving public care, either in nursing homes or in home care services.

\section{Background}

\section{The welfare state and the Norwegian long-term care}

Norway is placed within the Nordic welfare model, characterised by a high degree of governmental control, tax-financed interventions and welfare programmes (Christensen \& Wærness, 2018; Esping-Andersen, 1990; Kautto, 2010). LTC services consist of nursing homes $(\mathrm{NH})$ and home care $(\mathrm{HC})$ services, and both branches are a part of a comprehensive infrastructure of statutory services administered by local authorities (municipalities). $\mathrm{NH}$ constitute a principal public care alternative and are regarded as vitally important, particularly for the oldest citizens with advanced chronic illnesses and multiple diagnoses (Næss et al., 2013). NH are generally associated with severe loss of health (physical and/or psychological), but they are also connected to the loss of a private home, individual status and freedom to shape everyday life (Bergland \& Kirkevold, 2006; Malmedal et al., 2009; Ågotnes, 2016). NH in Norway have previously been under criticism for not offering enough assistance to their residents, and the quality of care has been repeatedly discussed (Malmedal et al., 2009). One study found that staff were not sufficiently present during meals and did not provide enough assistance to the residents in the areas of personal care, hygiene and psychosocial care (Slagsvold, 1999). After several years of intellectual and practical activity to improve the facilities, researchers stated that quality in nursing homes remains a major concern (Kjøs et al., 2010). Recent studies suggest that general care is at a relatively high level, while physical and social activities in nursing homes is relatively low (Førland \& Rostad, 2019). In response to these 
concerns, campaigns have been launched to increase the level of activities in nursing homes. It is assumed by the government that volunteers can be involved in such tasks (Helse- og omsorgsdepartementet, 2013; Helse-og omsorgsdepartementet 2017) and contribute to improved services.

Home care $(\mathrm{HC})$ constitutes the second - and currently the largest - branch of LTC in Norway. Its services originated in the third sector in the beginning of the 1970s, consisting of national and local associations of women and local churches undertaking voluntary work. Vabø and Szebehely (2012) claimed that voluntary organisations have played a role in pressuring the state to take responsibility for the care of elderly individuals. In Norway, HC services have since developed from providing mostly practical assistance to elderly care receivers at the outset; it is now comprised of advanced medical tasks and care (Fjørtoft et al., 2020). This is a consequence of political reforms aimed to move the responsibility for general medical follow-up tasks from the specialist level - in hospitals - to the general level within the municipalities (Ahgren, 2014; Gautun \& Syse, 2017). The number of HC recipients have grown considerably over the last decades. The user groups have become diverse and represent all age groups, from young children to elderly individuals at the end of life. Central beneficiaries of home care are people with physical disabilities, mental illnesses and handicaps, drug-related disorders and progressive illness.

Nursing home recipients in long-term care are increasingly frail elderly individuals characterised by multi-morbidities, cognitive failure and polypharmacy (Helvik et al., 2010) leading to an increased need for advanced nursing competence (Bing-Jonsson et al., 2016). More time is spent on caring for the acutely and critically ill as well as on documentation and reporting, which leaves professionals with less time for direct social contact with residents (Vabø, 2012).

Against this background, official documents such as white paper no. 25 (20052006) specified the importance of enhancing the number and types of social and cultural activities in long-term care (Helse - og omsorgsdepartementet, 2006). This was followed up through recent governmental documents (e.g., white paper 15 (2017-2018) "A full life - all your life. A Quality Reform for Older Persons"; Helse- og omsorgsdepartementet, 2017). A recent study confirmed that the three most common activities involving voluntary work are cultural activities, social activities and visiting schemes and can be interpreted 
as complementary to the formal LTC services as well as constructed to increase the well-being of residents (Skinner et al., 2018).

\section{Contextual differences between home care and nursing homes}

In sociological theory, nursing homes are institutions that contain a formal and informal structure with permanence and duration (Repstad, 1991). Material conditions such as physical and architectural structure provide frameworks and guidelines for the social structure in the nursing home. The degree of privacy for institutional residents is determined by the construction of the building in addition to how dependent the residents are on help from employees to perform daily functions. Repstad (1991) argued that other important organizational structures in nursing homes are the division of labour among employees, power and control, direction of communication and the firmness of the structure (i.e., to what extent it is deemed acceptable to deviate from the existing communication and power structures, allowing flexibility and improvisations).

Nursing homes are institutions - either publicly owned or owned by private organizations - for persons with lower levels of functions characterised by multi-morbidity and complex medical conditions (Gulla, 2018). Nursing homes are also run with strict guidelines and rules of operation. The residents must follow these requirements on the premises of the institution. Many residents are living under the same roof and receive LTC services from the same staff members; they must adapt to the daily routines guiding the pace of the institution. For example, there are set times for when meals are served, when medication is given, when the physician is visiting, and so on. There are also generally set times for social and cultural activities. The residents have their own rooms that ideally have a "homelike" look (Hauge, 2004). However, the residents are often too sick to regulate who is coming and going in and out of their "home", and staff are likely to enter accordingly. The residents in $\mathrm{NH}$ are mostly fully dependent on the care staff for carrying out daily functions such as personal care, assistance to move and attending social activities; residents therefore have asymmetric relations to the care staff (Garsjø, 2008).

In comparison, care recipients living in their own home are in their personal space and hold property rights. The owner can independently make decisions as to the appearance of the home and has autonomy and independence to decide who can access it (Twigg, 1999). He/she is also free to form rules for the house and its members and to decide both how the home will be 
maintained and what behaviour is expected from guests. Upon illness and old age, the home dweller may have to accept assistance and leave the independence to others, making the home environment potentially more challenging to handle (Haak et al., 2011). Home care staff primarily perform their work tasks individually and make judgements alone by taking an autonomous role looking after the specific and changing needs of home dwellers (Vabø, 2012). A visit from the home care lasts from 10-40 minutes, depending on the task for which assistance is required (Førland et al., 2017). Shaping different settings for both ageing and receiving care, these contextual variables for nursing homes and individual homes consist of different organizational features, codes of conduct and power relations (Scharlach, 2017) and also different operational setting to volunteers.

\section{The volunteers and their motives}

Volunteers' motives seem to have become more complex and varied in recent years, as have the group of volunteers themselves (Bussell \& Forbes, 2001; Clary \& Snyder, 1999). Prior to 1990 , most voluntary work was based on membership in national voluntary organizations whose members shared common values. Over the last decade, volunteers are less attached to organizations and motives for volunteering are increasingly related to personal development for the volunteer (Wollebæk \& Sivesind, 2010; Wollebæk \& Selle, 2002) as a form of "organized individualism" (Wollebæk \& Sivesind, 2010). Habermann (2007) studied motives for volunteering in a Danish context and found a large variation. Motives included volunteering for a case one has sympathy for, learning (i.e., volunteers wanting to acquire new skills), identity (i.e., volunteers are a part of an identity and a meaning-forming project), values (i.e., to be able to transmit specific values and beliefs, such as religious beliefs, humanitarian ideals or ethical obligations), influence (i.e., volunteers looking for influence or recognition as a central person in a local community), companionship (i.e., desire for social affiliation with other people) or career (i.e., the work provides an experience that can be of use in the workplace). Haberman pointed out that the motives can be complex and composed in different manners; as an example, altruistic values can coincide in an individual with self-esteem thinking (Habermann, 2007). A similar panorama of motives was found in studies of the Norwegian volunteer centrals, and these encompassed situations such as realizing important humanitarian, religious or political values, learning (i.e., acquiring new skills), social reasons (i.e., the desire to belong to a group), work training (i.e., improving skills or preparing for paid employment) and so on (Lorentzen et al., 1995). 
With this background in mind, the purpose of this research is to discuss the scope and type of volunteer activities in long-term care, as well as the leader's perceptions of barriers for volunteer recruitment. This study argues that possibilities for voluntary work must be understood in the context of locality, the theoretical frameworks for "homes", "institutions", motives to volunteer and the development of the welfare state.

\section{Method}

In 2015, survey data was collected over a two-month period in a sample of 50 Norwegian municipalities. The municipalities constituted a municipal panel recruited by the Centre for Care Research - to assist with data for research. The municipalities constitute a stratified selection of small, medium and large municipalities across the country. An electronic questionnaire was developed based on a review of available literature concerning volunteering in Norwegian long-term care services. For the literature study. we initially searched for all possible written material on voluntary work in Norwegian long-term care. This topic was sparsely investigated, so we searched broadly at first, subsequently selecting research reports and papers with data from Norway and the Nordic settings. All referenced hindrances (barriers) and success criteria to voluntary work were highlighted while reviewing the literature, and these were kept in a separate document. The research group discussed the hindrances and the success criteria and grouped similar expressions of hindrances/success criteria together.

As a part of the questionnaire preparation, five qualitative interviews were carried out with experienced managers in LTC services from five different municipalities. This was done in order to strengthen the questionnaire items' relevance and framing. The questions consisted of what sort of ongoing voluntary activities the LTC service had, how the activities were organised, the level of contact between LTC services and the volunteers, estimations of weekly contribution from volunteers (volume), if and what sort of training was offered to volunteers and so on. The interviews contributed to informing the survey questionnaire. Drafts of the questionnaire were tested among leaders and staff who held the responsibility for voluntary work in nursing homes and the home care sector. Prior to the distribution of the questionnaire, a comprehensive recruitment process was undertaken to ensure that we 
recorded the opinions of the leaders holding the responsibility for coordinating the voluntary work.

The electronic questionnaire consisted of primarily closed-end, multiple-choice questions. It was stated at the beginning of the questionnaire that questions would be asked about voluntary activities that were organised in cooperation with the formal services/municipalities. Voluntary activities were defined as activities or services that were carried out using unpaid labour. Cooperation was defined as municipal involvement, such as economic support or direct municipal coordination of voluntary activities.

\section{Measures and analyses}

The study used a screening question which asked whether the service location had any activities with volunteer involvement in the last four weeks regarding the following thirteen areas: social activities, cultural activities, library/reading services, physical activities, visiting schemes, food delivery, practical assistance, day centres, helplines/counselling services, transport/taking out services, self-help groups, activities certified by volunteer organisations and other activities. An additional three questions were used in order to give an indication of the volume of voluntary contributions detected by staff in each of these activity/service categories. For each of the categories, respondents were initially asked to give an estimate of how many times voluntary activities were held in the unit in the last four weeks, followed by how many volunteers contributed each time, and finally, how long the activities lasted each time. The results were recalculated into the average number of hours spent by volunteers doing unpaid work per week for purposes of interpretation. The only data reported in the article came from LTC units that reported activity in the different categories and gave an estimate of the number of hours. The number of respondents from nursing homes and home care units and mean hours per month are summarised in Tables 2 and 3 below.

Potential hindrances to voluntary work were reviewed in the literature study with emphasis on Norwegian studies. Afterwards, categories of various hindrances were developed and discussed in the research group as well as with managers responsible for voluntary work. Finally, the following categories were included as potential hindrances in the study: lack of volunteers, poor flow of information between the stakeholders, highly vulnerable/weak recipients of care, uncertainty regarding financial support, lack of coordination 
by the municipal LTC services, cooperation overdependent on key persons, low interest in the municipal LTC services, competence among volunteers, excessively high cost of organising the cooperation, long distances between the centre and outskirts, difficulty for voluntary workers to get access to the place where care service is located, and professionals regarding voluntary work as threatening to their own work. The category of other reasons was included in addition to these categories so as to allow the respondents to describe in their own words the hindrances that were not mentioned in the list.

All respondents were asked background questions about their service location, position, length of service and professional background/education.

Descriptive analysis was used, including frequency distributions on prevalence of different types of voluntary work, mean number of hours of voluntary work per week and barriers to successful cooperation with voluntary workers considered by managers. Differences between the two sectors in activities and barriers was calculated via chi-square tests with Holm adjustment for multiple testing. SPSS IBM version 22 was used for these analyses.

\section{Table 1 Survey response rates}

\begin{tabular}{|c|c|c|c|}
\hline Long-term care unit & Respondents & Non-respondents & Response rate (\%) \\
\hline Nursing home & 128 & 34 & 79 \\
\hline Home care & 94 & 35 & 73 \\
\hline Other* & 22 & 3 & 88 \\
\hline Total & 244 & 72 & 77 \\
\hline
\end{tabular}




\section{Results}

Type and amount of voluntary work in nursing homes and home care services

The response rate was $77 \%$ involving 244 participants. There were no notable differences between the response rates among the $\mathrm{NH}$ and $\mathrm{HC}$ units. Among the respondents, $67 \%$ were educated nurses, $17 \%$ were other health/care professions and $16 \%$ had other types of education. The prevalence of voluntary work activities is presented in Table 2 below. Table 2 shows how common voluntary work in the different categories is, while Table 3 summarises the hours (mean) spent per week on the different activities in nursing homes and home services.

Table 2 Prevalence of different types of voluntary work in nursing homes and home care

\begin{tabular}{|l|l|l|l|l|}
\hline Category & $\begin{array}{l}\text { Nursing } \\
\text { homes } \\
(\mathbf{N = 1 2 8}), \% \\
(\mathbf{n})\end{array}$ & $\begin{array}{l}\text { Home } \\
\text { care } \\
(\mathbf{N}=94), \\
\%(\mathbf{n})\end{array}$ & $\begin{array}{l}\text { P- } \\
\text { value }\end{array}$ & $\begin{array}{l}\text { value } \\
\text { Holm }\end{array}$ \\
\hline Cultural activities (music, dance, theatre, etc.) & $80(102)$ & $36(34)$ & $<0.001$ & 0.001 \\
\hline Social activities (trips, social gatherings, etc & $67(86)$ & $36(34)$ & $<0.001$ & 0.001 \\
\hline Visiting schemes & $56(72)$ & $30(28)$ & $<0.001$ & 0.003 \\
\hline Physical exercise and activities & $30(38)$ & $27(25)$ & 0.662 & 1.000 \\
\hline Library/reading services & $27(35)$ & $9(8)$ & $<0.001$ & 0.003 \\
\hline Joy of life-certified activities & $27(34)$ & $7(7)$ & $<0.001$ & 0.003 \\
\hline Transport/taking out services & $15(19)$ & $28(26)$ & 0.026 & 0.132 \\
\hline Day centres & $5(7)$ & $14(13)$ & 0.035 & 0.142 \\
\hline Helplines/counselling services & $4(5)$ & $3(3)$ & 1.000 & 1.000 \\
\hline Food delivery for care recipients living at home & & $23(22)$ & $<0.001$ & 0.001 \\
\hline $\begin{array}{l}\text { Practical assistance for care recipients living at } \\
\text { home (e.g. snow clearing, food shopping)* }\end{array}$ & & $14(13)$ & $<0.001$ & 0.001 \\
\hline $\begin{array}{l}\text { Self-help groups (for anxiety, grief, loneliness, } \\
\text { etc.) }\end{array}$ & $2(3)$ & $4(4)$ & 0.463 & 1.000 \\
\hline Other activities & $27(34)$ & $6(6)$ & $<0.001$ & 0.002 \\
\hline
\end{tabular}


Table 3 Mean number of hours of voluntary work per week in nursing homes and home care

\begin{tabular}{|c|c|c|c|c|}
\hline Category & $\begin{array}{l}\text { Nursing } \\
\text { homes } \\
\text { (mean) }\end{array}$ & $\begin{array}{l}\text { Nursing } \\
\text { homes } \\
\mathrm{N}=\end{array}$ & $\begin{array}{l}\text { Home } \\
\text { care } \\
\text { (mean) }\end{array}$ & $\begin{array}{l}\text { Home } \\
\text { Services } \\
\mathrm{N}=\end{array}$ \\
\hline Day centres & 38.3 & 6 & 17.5 & 11 \\
\hline Joy of life-certified activities & 15.4 & 32 & 11.1 & 5 \\
\hline $\begin{array}{l}\text { Cultural activities (music, dance, theatre, } \\
\text { etc.) }\end{array}$ & 8.9 & 99 & 3.1 & 28 \\
\hline $\begin{array}{l}\text { Social activities (trips, social gatherings, } \\
\text { etc }\end{array}$ & 8.1 & 84 & 7.0 & 31 \\
\hline Physical exercise and activities & 5.0 & 37 & 2.5 & 20 \\
\hline Transport/taking out services & 4.8 & 16 & 3.8 & 20 \\
\hline Visiting schemes & 4.4 & 65 & 3.1 & 20 \\
\hline $\begin{array}{l}\text { Self-help groups (for anxiety, grief, } \\
\text { loneliness, etc.) }\end{array}$ & 2.2 & 3 & 0.3 & 2 \\
\hline Library/reading services & 1.1 & 32 & 2.8 & 7 \\
\hline Helplines/counselling services & 0.4 & 4 & 0.6 & 2 \\
\hline $\begin{array}{l}\text { Food delivery for care recipients living at } \\
\text { home }\end{array}$ & - & - & 12.0 & 17 \\
\hline $\begin{array}{l}\text { Practical assistance for care recipients } \\
\text { living at home (e.g. snow clearing, food } \\
\text { shopping)* }\end{array}$ & - & - & 3.1 & 11 \\
\hline Other activities & 6.0 & 27 & 2.2 & 5 \\
\hline
\end{tabular}

The results show that more voluntary work takes place in $\mathrm{NH}$ as compared to the HC sector (Table 2). The most common activities that are organised both in $\mathrm{NH}$ and $\mathrm{HC}$ with the contribution of volunteers are in the category of cultural and social activities, followed by visiting schemes. In nursing homes, physical activities and exercise, library services and Joy of Life-certified activities approved by a volunteer organisation are also frequent. In $\mathrm{HC}$, transportation, physical activities and food delivery are also activities frequently run by volunteers. The categories food delivery and practical assistance were only relevant to respondents in the home care field. The activities in day care centres as well as transport and taking out services are more commonly organised in $\mathrm{HC}$ than in $\mathrm{NH}$. 
Table 3 indicates that for most activities, more time was spent in nursing homes compared to home care services. However, the number of institutions varied considerably. In this study, the activity involving volunteer effort with the highest mean hours in both nursing homes and home care related to activities in day centres; 38.3 mean hours were recoded from nursing homes and 17.5 hours per week were recorded from home care. This is followed by Joy of Lifecertified activities, with 15.4 hours per week in nursing homes and 11.1 for home care. For all activities in both nursing homes and home care, nursing homes had a higher number of mean hours.

\section{Hindrances to voluntary work}

The respondents were asked to select the three most common hindrances to successful cooperation with volunteers. Table 4 shows that lack of volunteers was the most important barrier recorded by the managers from both $\mathrm{HC}$ and $\mathrm{NH}$. Lack of coordination from the municipal care services was equally seen as a common hindrance by respondents from both groups.

Respondents from the $\mathrm{HC}$ scored poor flow of information as a hindrance more often than the respondents from the $\mathrm{NH}(\mathrm{p}=0.035)$. The same applies to low interest in the municipality, scored as an even greater hindrance by respondents from home care than the respondents from the nursing homes $(p$ $=0.009$ ).

Respondents from the $\mathrm{NH}$ scored cooperation overdependent on particular individuals as a more frequent hindrance than respondents from the $\mathrm{HC}(\mathrm{p}=$ 0.015). For other categories, there are only small variations between the responses given by the two sectors.

With correction for multiple testing by Holm's procedure, all P-values are $\geq$ 0.118 . However, our results shed some light on voluntary work in the two sectors and this will be discussed below in relation to the topics of volunteer recruitment and coordination procedures. 
Table 4 Three most important barriers to successful cooperation with volunteers.

Presented in percent

\begin{tabular}{|c|c|c|c|c|}
\hline $\begin{array}{l}\text { What would you consider to be the three most } \\
\text { important barriers to successful cooperation with } \\
\text { voluntary workers at the nursing home/home care } \\
\text { sector where you are employed }\end{array}$ & $\begin{array}{l}\text { Total } \\
(\mathrm{N}=222)\end{array}$ & $\begin{array}{l}\text { Nursing } \\
\text { Homes } \\
\text { (N=128) }\end{array}$ & $\begin{array}{l}\text { Home } \\
\text { services } \\
(\mathrm{N}=94)\end{array}$ & $\begin{array}{l}\text { P- } \\
\text { value }\end{array}$ \\
\hline Lack of volunteers & 76 & 77 & 76 & 0.875 \\
\hline Poor flow of information between the stakeholders & 36 & 30 & 44 & $0.035^{*}$ \\
\hline Lack of coordination by the municipal care services & 34 & 36 & 32 & 0.569 \\
\hline Co-operation overdependent on key persons & 28 & 34 & 19 & $0.015^{*}$ \\
\hline Too vulnerable/weak recipients of care & 21 & 21 & 21 & 1.000 \\
\hline Uncertain financial support & 20 & 23 & 15 & 0.128 \\
\hline Low interest in the municipality & 16 & 10 & 23 & $0.009^{*}$ \\
\hline Competence among the volunteers & 14 & 15 & 13 & 0.700 \\
\hline Overhigh costs of organising the cooperation & 10 & 9 & 11 & 0.822 \\
\hline Other reasons & 8 & 9 & 6 & 0.466 \\
\hline Long distances between centre/outskirts & 7 & 8 & 6 & 0.796 \\
\hline $\begin{array}{l}\text { It is hard for the voluntary workers to get access to the } \\
\text { place where the care service is located }\end{array}$ & 6 & 4 & 9 & 0.246 \\
\hline $\begin{array}{l}\text { The professionals regard voluntary work as } \\
\text { threatening to their own work }\end{array}$ & 5 & 9 & 1 & $0.015^{*}$ \\
\hline
\end{tabular}




\section{Discussion}

The three most commonly involved activities in voluntary work within $\mathrm{NH}$ and $\mathrm{HC}$ settings are cultural activities, social activities and visiting schemes. However, the prevalence of voluntary work in long-term care is distributed differently. In our study, respondents reported that volunteers spent more time (measured as mean hours per week) in nursing homes compared to the home care sector. As for the variation between the two sectors, it can be assumed that service recipients in $\mathrm{HC}$ might have less demand for volunteers, as they are generally younger than residents in $\mathrm{NH}$. However, it is known that recipients of $\mathrm{HC}$ have increasingly complex, high-care needs independent of their age, including psychiatric health problems and addiction (Førland \& Folkestad, 2016; Hamran \& Moe, 2012; Otnes, 2015). So younger reservice recipients do not necessarily equate to less demand for support and care. The two sectors experienced an assortment of common hindrances. Most respondents reported lack of volunteers as a main barrier. The difficulties of initiating and recruiting volunteers in care is also evident in other Norway- and internationally-based studies (Andfossen, 2016; Bussell \& Forbes, 2001). It is argued that a coordinator is needed to mobilize, recruit and assume the responsibility for the contribution from volunteers (Hillestad \& Tessem, 2015). Managers assuming this role needs to receive training in how to understand and manage volunteers (Wilson \& Pimm, 1996) and develop procedures for recruitment (Disch \& Vetvik, 2009; Hoad, 2002; Netting, Nelson Jr, Borders, \& Huber, 2004).

Respondents from the HC reported low interest in the municipality as a more frequent barrier than the respondents from $\mathrm{NH}$. This indicates that recruitment initiatives might be particularly low in this branch of long-term care. It may also reflect the complexity of the home context where voluntary work crosses between many boundaries: formal and informal, micro and macro, public and private as well as medical and social care (Burau et al., 2007). As an example, decisions are still somewhat unclear as to who should assume responsibility for the various needs of a home dweller and how tasks should be shared among the different providers (e.g. home care service, volunteers, informal carers). Knowledge is sparse regarding factors that influence the decision of who provides help and care to elderly people living at home (Hellström \& Hallberg, 2004). Another factor that may potentially explain low interest in the community can be the volunteer's lack of willingness or ability to visit home dwellers with increasingly complex health conditions (Bing-Jonsson et al., 2016). Handling difficult situations with vulnerable home dwellers may prove to 
be a demanding task for volunteers to take on, especially when they are operating on their own in individual homes without support from other volunteers or care staff (Solbjør et al., 2014; Tingvold \& Olsvold, 2018).).

The respondents from the $\mathrm{HC}$ services reported poor flow of information as a more important barrier than respondents from NHs. Reforms over recent years have triggered changes in how home care staff carry out their work. Staff are directed increasingly towards serving a specific need of the home dweller (e.g., cleansing a wound, bringing medication, giving a bath) and do not have the same flexibility to consider various needs on the spot and place priority when entering the houses of the home dwellers (Vabø, 2012). Less time spent with home dwellers gives less time to observe the resident, register changing needs (Vabø, 2012) and communicate about psychosocial needs (Vik \& Eide, 2012). A lack of procedures for how staff in home care can involve volunteers in providing care for lonely older people is missing, as well as knowledge about how this cooperation can be organised (Hoad, 2002; Rønning, 2011). Confidentiality is also discussed as a hindrance in regards to the sharing of personal information, as staff are afraid of passing on sensitive information about home dwellers to volunteers (Øhrn, 2019). Furthermore, coordinators of voluntary work may be reluctant to send volunteers to home dwellers with complex or demanding care needs, such as mental illnesses, substance abuse and terminal illness (Tingvold \& Olsvold, 2018). Coordinators may consider whether or not it is justifiable to send volunteers out to visit a service recipient with such challenging health and care needs. In a study, coordinators were concerned about those volunteers who visited care receivers in their homes; the volunteers had less opportunity to seek guidance and support in an unexpected event, as compared to volunteers in a nursing home with staff members present at all times (Tingvold \& Olsvold, 2018).

Additionally, service recipients with complex health situations in both nursing homes and home care have changing - and often unpredictable - days; this leads to changing opinions in terms of whether a volunteer should perform a visit or not (Tingvold \& Skinner, 2019). It is unknown whether or not home dwellers are more hesitant to admit volunteers in their private homes - as compared to meeting volunteers in nursing homes. However, a staff member who was interviewed in the pilot of this study claimed that - compared to home dwellers - it was easier to include nursing home residents in voluntary activities. She stated: 
At the nursing home, everyone lives in the same building. So you just knock on a door and say to [name of the person who lives there]: 'It's a lovely day so now we're going outside.' You don't do that in the home care service.

This quote illustrates that contextual framework matters, and the autonomy of service recipients are considered differently where home dwellers are concerned. It is within their rights to refuse visits and decide when the visit or activity is over. As mentioned previously, home dwellers represent a large group of people with different needs and reasons for receiving care. Hence, it is difficult to offer them a fixed, set activity or a common approach to contact. In comparison, voluntary work in nursing homes is often scheduled at fixed times of the day and is embedded in the daily or weekly routines of the $\mathrm{NH}$. The decision to take part is not necessarily left to the residents.

The motives of the volunteers and how they interact with the contextual framework are relevant to our findings. Similar to staff in $\mathrm{HC}$, volunteers need to function independently in a private home. The volunteer does not know how the health of the home dweller is from one day to the next and must make individual decisions on how to respond to care needs or situations that might arise. In comparison, there are always staff members present in NHs. In addition to this, there are often several volunteers taking part in the same activity, making similar observations that they can subsequently discuss. The volunteers in this context can assist each other if there is need for support, and they can also ask staff for clarification or assistance. If the motive for the volunteer is to socialise, gain work experience, increase learning skills or language, the opportunity to achieve this would be far better in an environment where the volunteer can get support, advice and information (i.e., in a nursing home). A recent article discussed engagement, motivation and barriers to volunteering among post-World War II baby-boomers and concludes that more flexible forms of involvement of volunteers need to be accommodated in the future (Hansen \& Slagsvold, 2020). For volunteering in LTC, such flexibility can be hard to accomplish. This is especially true in the case of home care, as the contact between a volunteer and a service recipient is often more personal in comparison to volunteer activities in nursing homes that are directed towards a group of residents. A theme in the investigation of volunteering motivations in actual situations is that volunteer behaviours do not depend solely on the person or on the situation; rather, they depend on the interaction 
of person-based dynamics and situational opportunities (Clary \& Snyder, 1999).

Finally, we wish to relate the topic of recruitment of volunteers in LTC to broader trends of development in the welfare state and the ageing policy. Every four years, the Norwegian government publishes a perspective report to the parliament (Perspektivmeldingene) concerning future challenges for the country and the government. Since the early 2000s, these reports have emphasized an increase in costs connected to changes in age composition as well as how this will increase demand for health and long-term care services; it mentions that relatively fewer workers will have to shoulder the burden of an increased older non-working population (Ministry of Finance, 2017). Healthy and active ageing as well as increased informal work are seen as two solutions that can mitigate the challenges posed for public finances as a result of increased longevity (Ministry of Health and Care Services, 2015). The growing interest for the potentials of voluntary work in LTC can be perceived as a response to such discourses of sustainability of the welfare state, both in Norway and in many other countries (Broese van Groenou \& Boer, 2016; Fyfe \& Milligan, 2003; Hussein \& Manthorpe, 2005). By prioritizing home care, ageing in place and volunteerism, it can be asserted that policymakers are attracted to the possibility of cost savings over expensive institutional care (Grabowski, 2006). In most countries - including Norway - informal caregiving, and especially family caregiving, is a backbone in LTC. Their volume of caregiving is under substantial pressure for several reasons; the number of children per dependent elderly is decreasing, the labour market participation among women and older people is increasing and the professional competence required in LTC is expanding in addition to the uncertainty of the home dweller to accept contributions from volunteers. In the predominant way of narrating the potential of volunteerism, these patterns seem to be neglected. The realism of strengthening the role of volunteers in LTC - especially in the home care context - can be debated and seen as wishful thinking as the challenges are quite obvious.

\section{Strengths and limitations}

The strength of the study lies in the new insight provided into healthcare professionals' perceptions, specifically those of voluntary service contributions in a contextual perspective. Prior to this study, a lack of quantitative data was present in regard to the following: how management and staff in LTC were experiencing voluntary work in nursing homes and home care, which activities 
volunteers were involved in and how often volunteers were involved in those activities. Self-reported estimates by volunteers themselves may have yielded different, and perhaps higher, levels of involvement. A qualitative study with both service recipients and volunteers would have provided deeper insight in the subject matter. A limitation of our data set is that our survey did not differentiate between individual volunteers and volunteers within formal organizations. Volunteer perspectives (those representing both formal organisations and individual volunteers) should be studied carefully in future research, particularly those concerning the importance of context in LTC service voluntary work.

\section{Conclusion}

Different challenges are connected to contributions from volunteers in the two aforementioned branches of long-term care. Nursing homes in Norway are institutions driven by formal rules and procedures. Volunteer activities are organised to fit the schedules and take place in common rooms suitable for social gatherings with several residents at the same time. Volunteers may benefit from partaking in activities with several volunteers in a social network. On the other hand, home dwellers stay in more individualised contexts in their own houses with more autonomy to make their own decisions. Given that home care services are going to serve most of the elderly in the future - as suggested by political authorities - our findings indicate some concerns. First, we pose the following question: are volunteers willing to volunteer in the homes of the elderly - without support from others present in the home - who have various, potentially complex care needs? Second, we postulate that voluntary work in the context of private homes is dependent on the willingness and autonomy of the home dweller to accept contributions from volunteers. In a home care setting, the roles and tasks among the home dweller, next of kin, care services and volunteer are more informal and are often blurred compared to the nursing home setting. On a societal level, the government strives for increased voluntary work in LTC. In the context of an expected increased home care sector, this can be seen as an effort to meet expected rises in public expenditure. However, the realism in this effort can be debated. An increased focus is needed in acknowledging the various contexts in which volunteers operate, especially regarding the large variation of health and care needs among home dwellers. Volunteering in groups of two or more, voluntary activities taking place outside private homes in local communities, providing 
volunteers with sufficient information about the home dwellers and discussing expectations carefully beforehand can potentially aid this dire situation.

\section{Funding}

This work was funded by the Research Council of Norway through the HELSEVEL Programme (Health, Care and Welfare Services Research) as part of the research project, 'Voluntary Work in Norwegian Long-term Care Prevalence, Forms, Interaction with Professionals and Potentials for the Future'.

\section{Acknowledgements}

During the formation of this research, the first author was a visiting scholar to the University of California at Berkeley, and wishes to thank Professor Andrew Scharlach, School of Social Welfare, UC Berkeley for the valuable comments and discussions. Many thanks are also in order for Marianne Sundlisæter Skinner and Maren Kristine Raknes Sogstad, who helped with factors of research from tables and comments to the first draft. Additionally, great thanks are given to Tore Wentzel Larsen, who provided statistical assistance. 


\section{References}

Ahgren, B. (2014). The path to integrated healthcare: various Scandinavian strategies. International Journal of Care Coordination, 17(1-2), 52-58. https://doi.org/10.1177/2053435414540606

Andfossen, N. B. (2016). The potential for collaborative innovation between public services and volunteers in the long-term care sector. Innovation Journal, 21(3).

Andfossen, N. B. (2020). Co-production between long-term care units and voluntary organisations in Norwegian municipalities: a theoretical discussion and empirical analysis. Primary Health Care Research \& Development, 21. https://doi.org/10.1017/S1463423620000341

Bergland, Å., \& Kirkevold, M. (2006). Thriving in nursing homes in Norway: Contributing aspects described by residents. International Journal of Nursing Studies, 43(6), 681-691. https://doi.org/10.1016/j.ijnurstu.2005.09.006

Bing-Jonsson, P. C., Hofoss, D., Kirkevold, M., Bjørk, I. T., \& Foss, C. (2016). Sufficient competence in community elderly care? Results from a competence measurement of nursing staff. BMC nursing, 15(1), 5. https://doi.org/10.1186/s12912-016-0124-z

Broese van Groenou, M., \& Boer, A. (2016). Providing informal care in a changing society. Social, Behavioural and Health Perspectives, 13(3), 271-279. https://doi.org/10.1007/s10433-016-0370-7

Burau, V. D., Theobald, H., \& Blank, R. H. (2007). Governing home care: A crossnational comparison. Edward Elgar Publishing. https://doi.org/10.4337/9781847206862

Bussell, H., \& Forbes, D. (2001). Understanding the volunteer market: The what,where, who and why of volunteering. International Journal of Nonprofit and Voluntary Sector Marketing, 7(3), 244-257. https://doi.org/10.1002/nvsm.183

Christensen, K., \& Wærness, K. (2018). Long-term care services in Norway. A historical sociological perspective. In K. Christensen \& D. Pilling (Eds.), The Routledge Handbook of Social Care Work Around the World (pp. 15-28). Adingdon: Oxon: Routledge. https://doi.org/10.4324/9781315612805-2

Clary, G. E., \& Snyder, M. (1999). The Motivations to Volunteer: Theoretical and Practical Considerations. Current Directions in Psychological Science, 8(5), 156-159. https://doi.org/10.1111/1467-8721.00037

Cour, A. I. (2019). The management quest for authentic relationships in voluntary social care. Journal of Civil Society, 15(1), 1-17. https://doi.org/10.1080/17448689.2018.1551864

Disch, P. G., \& Vetvik, E. (2009). Framtidas omsorgsbilde: slik det ser ut på tegnebrettet : omsorgsplanlegging i norske kommuner : status i 2009 utfordringer mot 2015 (Vol. nr. 1/2009). [Arendal]: Senter for omsorgsforskning, Sør.

Esping-Andersen, G. (1990). The three worlds of welfare capitalism. Cambridge: Polity Press. 
Fensli, M., Skaar, R., \& Söderhamn, U. (2012). Frivilligsentral og offentlig omsorgsamhandling til brukers beste [Volunteer centrals and public care cooperation to the best for the service receipients]. Nordisk Sygeplejeforskning. https://doi.org/10.18261/ISSN1892-2686-2012-01-08

Folkestad, B., Christensen, D. A., Strømsnes, K., \& Selle, P. (2015). Frivillig innsats i Noreg 1998-2014: Kva kjenneteikner dei frivillige og kva har endra seg? Rapport fra Senter for forskning på sivilsamfunn og frivillig sektor.

Fredriksen, E., Martinez, S., Moe, C. E., \& Thygesen, E. (2020). Key challenges and best practices in the coordination of volunteers in healthcare services: $A$ qualitative systematic review. Health \& social care in the community. https://doi.org/10.1111/hsc. 13261

Fyfe, N. R., \& Milligan, C. (2003). Out of the shadows: exploring contemporary geographies of voluntarism. Progress in human geography, 27(4), 397-413. https://doi.org/10.1191/0309132503ph435oa

Fjørtoft, A. K., Oksholm, T., Førland, O., Delmar, C., \& Alvsvåg, H. (2020). Balancing contradictory requirements in homecare nursing-A discourse analysis. Nursing open.

Førland, O, Fagertun, A, Hansen, R \& Kverndokk. (2019). Normtider til besvær. Evaluering av endringene i normtider for hjemmetjenestene i Bergen kommune. [The Inconvenience of Standard Times. Evaluation of Changes in Standard Time for Home-Care Services in Bergen Municipality]. Vol. nr 4/2017. [Bergen] Senter for omsorgsforskning, Vest.

Førland, O. (2015). Hva er frivillig innsats i omsorgssektoren? [What is volunteering in the Care Sector]. In L. H. Jensen (Ed.), Frivillighet i omsorgssektoren [Volunteering in the Care Sector] (pp. 21-23). Bergen: Aldring og Helse.

Førland, O., \& Folkestad, B. (2016). Hjemmetjenestene i Norge i et befolknings- og brukerperspektiv. En populasjonsstudie basert på innbyggerundersøkelsene fra 2010, 2013 og 2015 [The Home Care Services in Norway in a population and user perspective. A study based on population surveys from 2010, 2013 and 2015]. Senter for omsorgsforskning. Rapportserie nr. 1-2016.

Førland, O., \& Rostad, H. M. (2019). Variasjon og uønsket variasjon $i$ kvalitet $i$ omsorgstjenestene - En kunnskapsoppsummering [Variation and unwanted variation in quality in the Care Services - A summary of knowledge]. Senter for omsorgsforskning. Rapportserie nr.1-2019.

Garsjø, O. (2008). Institusjon som hjem og arbeidsplass: et arbeidstaker-og brukerperspektiv: Gyldendal akademisk.

Gautun, H., \& Syse, A. (2017). Earlier hospital discharge: a challenge for Norwegian municipalities. Nordic Journal of Social Research, 8, 1-17. https://doi.org/10.7577/njsr.2204

Grabowski, D. C. (2006). The cost-effectiveness of long-term care services: review and synthesis of the most recent evidence. Medical Care Research and Review, 63(1), 3-28. https://doi.org/10.1177/1077558705283120

Greenfield, E. A., Scharlach, A. E., \& Davitt, J. K. (2016). Organizational Charactistics and Volunteering in Age Friendly Supportive Service Initiatives. Nonprofit and 
Voluntary Sector Quarterly, 45, 931-948.

https://doi.org/10.1177/0899764015621620

Groenou, M. v., \& De Boer, A. H. (2016). Providing informal care in a changing society. European Journal of Ageing, 13, 271-279. https://doi.org/10.1007/s10433-0160370-7

Gulla, C. (2018). A fine balance: drug use in Norwegian nursing homes. (Doctoral degree PhD), Bergen.

Haak, M., Malmgren Fänge, A., Iwarsson, S., \& Dahlin-Ivanoff, S. (2011). The importance of successful place integration for perceived health in very old age: a qualitative meta-synthesis. International Journal of Public Health, 56, 589-595. https://doi.org/10.1007/s00038-011-0282-4

Habermann, U. (2007). En postmoderne helgen? Om motiver til frivillighed. København: Muesum Tusculanum.

Hager, M. A., \& Brudney, J. L. (2015). In search of strategy: Universalistic, contingent, and configurational adoption of volunteer management practices. Nonprofit Management and Leadership, 25(3), 235-254. https://doi.org/10.1002/nml.21123

Hamran, T., \& Moe, S. (2012). Yngre og eldre brukere i hjemmetjenesten - ulike behov eller forskjellsbehandling: flerfaglig praksis i et interaksjonsteoretisk perspektiv. Gjøvik: Høgskolen i Gjøvik.

Hansen, T., \& Slagsvold, B. (2020). An "Army of Volunteers"? Engagement, Motivation, and Barriers to Volunteering among the Baby Boomers. Journal of gerontological social work, 1-19.

Hauge, S. (2004). Jo mere vi er sammen, jo gladere vi blir?: Ein feltmetodisk studie av sjukeheimen som heim (Vol. no. 208). https://openarchive.usn.no/usnxmlui/handle/11250/2606961

Hellström, Y., \& Hallberg, I. R. (2004). Determinants and characteristics of help provision for elderly people living at home and in relation to quality of life. Scandinavian Journal of Caring Sciences, 18(4), 387-395. https://doi.org/10.1111/j.1471-6712.2004.00291.x

Helvik, A.-S., Engedal, K., \& Selbæk, G. (2010). The quality of life and factors associated with it in the medically hospitalised elderly. Ageing \& mental health, 14(7), 861-869. https://doi.org/10.1080/13607861003801003

Hillestad, E., \& Tessem, J. (2015). Frivillighet i eldreomsorgen - hvorfor og hvordan? In M. Sætrang Holm \& S. Husebø (Eds.), En verdig alderdom. Omsorg ved livets slutt. Bergen: Fagbokforlaget.

Hoad, P. (2002). Drawing the line: the boundaries of volunteering in the community care of older people. Health \& social care in the community, 10(4), 239-246. https://doi.org/10.1046/j.1365-2524.2002.00361.x

Hussein, S., \& Manthorpe, J. (2005). An International Review of the Long-Term Care Workforce. Journal of Ageing and Social Policy, 17(4), 75-94. doi:10.1300/J031v17n04_05 https://doi.org/10.1300/J031v17n04_05 
Ingebretsen, R. (2005). Kommunikasjon ved demens-en arena for samarbeid (8278942153). Retrieved from Oslo:

https://doi.org/10.7577/nova/rapporter/2005/13

Jegermalm, M., Hermansen, J., \& Fladmoe, A. (2019). Beyond Voluntray Organizations and the Welfare State: Patterns of Informal Helping in the Scandinavian Countries. Civic Engagement in Scandinavia, 95-111. https://doi.org/10.1007/978-3-319-98717-0_4

Johansen, V., \& Lofthus, A. (2011). Kommunenes rekruttering til og oppfølging av frivillig omsorg [Municipalities recruitment and follow up of volunteer carers]. ØF-notat nr.: 11/2011. Retrieved from http://www.ostforsk.no/old/images/notater/112011.pdf

Kautto, M. (2010). The Nordic Countries. In F. G. Castles (Ed.), The Oxford Handbook of the Welfare State. Oxford: Oxford University Press. https://doi.org/10.1093/oxfordhb/9780199579396.003.0040

Kjøs, B. Ø., Botten, G., Gjevjon, E. R., \& Romøren, T. I. (2010). Quality work in longterm care: the role of first-line leaders. International Journal for Quality in Health Care, 22(5), 351-357. https://doi.org/10.1093/intqhc/mzq035

Lorentzen, H., Brekke, J.-P., \& Andersen, R. K. (1995). Felleskapets fundament: sivilsamfunnet og idealismen. Oslo: Pax.

Luijkx, K. G., \& Schols, J. M. G. A. (2018). Volunteers in Palliative Care Make A Difference. Journal of Palliative Care, 25(1), 30-39. https://doi.org/10.1177/082585970902500104

Malmedal, W., Ingebrigtsen, O., \& Saveman, B.-I. (2009). Inadequate care in Norwegian nursing homes - as reported by nursing staff. Scandinavian Journal of Caring Sciences, 23(2), 231-242. https://doi.org/10.1111/j.14716712.2008.00611.x

Ministry of Finance. (2017). Long-term Perspectives on the Norwegian Economy 2017. Oslo: Ministry of Finance Retrieved from https://www.regjeringen.no/contentassets/aefd9d12738d43078cbc647448bbe ca1/en-gb/pdfs/stm201620170029000engpdfs.pdf

Ministry of Health and Care Services (2006). Mestring, muligheter og mening: Framtidas omsorgsutfordringer (St.meld.nr. 25 (2005-2006)). [Future care challenges].Oslo:Regjeringen.

Ministry of Health and Care Services (2015). Nasjonal strategi for frivillig arbeid på helse- og omsorgsfeltet (2015-2020) [National strategy for voluntary work in the health and care sector]. Oslo: Regjeringen.

Ministry of Health and Care Services (2013). Morgendagens omsorg (Meld. St. 29 (2012-2013)) [Future Care]. Oslo: Regjeringen.

Ministry of Health and Care Services (2017). Leve hele livet. En kvalitetsreform for eldre.[A full life - all your life. A quality Reform for Older Persons]. Oslo: Regjeringen.

Ministry of Health and Care Services (2013). Fremtidens primærhelsetjeneste - nærhet og helhet. [The primary health and care services of tomorrow - localised and integrated]. White Paper no. 26 (2014-2015). Oslo: Regjeringen. 
Netting, F. E., Nelson Jr, H. W., Borders, K., \& Huber, R. (2004). Volunteer and paid staff relationships: Implications for social work administration. Administration in Social Work, 28(3-4), 69-89. https://doi.org/10.1300/J147v28n03_04

Næss, A., Havig, A. K., \& Vabø, M. (2013). Contested spaces-The perpetual quest for change in Norwegian nursing homes. In A. Hujala, S. Rissanen, \& S. Vihma (Eds.), Designing wellbeing in elderly care homes (Vol. 2, pp. 68-83). Helsinki: Aalto University publication series Crossover.

Otnes, B. (2015). Utviklingen i pleie- og omsorgstjenestene 1994-2013. Tidsskrift for omsorgsforskning, 1, 48-61. https://doi.org/10.18261/ISSN2387-5984-201501-10

Repstad, Pål (1991). Institusjonssosiologi. Tano A.S, Otta

Romsaas, A. (2011). Frivillighet - aktiv omsorg. Kartleggingsprosjekt fra Fylkesmannen i Oslo og Akershus Oslo: Oslo kommune. Bydel Bjerke. Utviklingssenter for hjemmetjenester.

Rønning, R. (2011). Frivillige og lønnende på samme lag. Om styrking av den frivillige innsatsen i omsorgsarbeidet i samspill med offentlig sektor [Volunteers and paid workers on the same team. Enhancing the contributions from volunteers in pulic care]. Lillehammer: Østlandsforskningsrapport.

Scharlach, A. E. (2017). Ageing in context: Individual and Environmental Pathways to Ageing-Friendly Communities. The Gerontologist, 57(4), 606-618. https://doi.org/10.1093/geront/gnx017

Skinner, M. S., Sogstad, M. K. R., \& Tingvold, L. (2018). Voluntary work in the Norwegian long-term care sector: complementing or substituting formal services? European Journal of Social Work, 1-13. https://doi.org/10.1080/13691457.2018.1462767

Skinner, M. S., Lorentzen, H. W., Tingvold, L., Sortland, O. E., Andfossen, N. B., \& Jegermalm, M. (2020). Volunteers and informal carers' contributions and collaboration with staff in Norwegian long-term care. Journal of Ageing \& Social Policy. https://doi.org/10.1080/08959420.2020.1745988

Slagsvold, B. (1999). Norsk eldreomsorg: Hvor dårlig er dårlig? [Norwegian long-term care. How poor is poor?]. Aldring \& Helse, 3, 12-16.

Snyder, M., \& Omoto, A. M. (2008). Volunteerism: Social issues perspectives and social policy implications. Social Issues and Policy Review, 2(1), 1-36. https://doi.org/10.1111/j.1751-2409.2008.00009.x

Solbjør, M., Ljunggren, B., \& Kleiven, H. H. (2014). Samarbeid mellom frivillig sektor og kommunale tjenester på pleie-og omsorgsfeltet. En kvalitativ studie. Nordisk tidsskrift for helseforskning, 10(1), 43-55. https://doi.org/10.7557/14.3009

Tingvold, L., \& Olsvold, N. (2018). Not just" sweet old ladies"-challenges in voluntary work in the long-term care services. Nordic Journal of Social Research, 9, 3146. https://doi.org/10.7577/njsr.2174

Tingvold, L., \& Skinner, M. S. (2019). Challenges in the coordination of volunteer activities in long-term care services. International Journal of Care and Caring. https://doi.org/10.1332/239788219X15473078841850 
Twigg, J. (1999). The spatial ordering of care: public and private in bathing support at home. Sociology of Health \& IIIness, 21(4), 381-400.

https://doi.org/10.1111/1467-9566.00163

Vabø, M. (2012). Norwegian home care in transition-heading for accountability, offloading responsibilities. Health \& social care in the community, 20(3), 283291. https://doi.org/10.1111/j.1365-2524.2012.01058.x

Vabø,M \& Szebehely, M (2012). A caring state for all older people? In A.Anttonen, L. Häikiö \&K. Stefanson (Eds), Welfare state, Universalism and Diversity (p.121144). Cheltenham: Edward Elgar.

Vik, K., \& Eide, A. H. (2012). The exhausting dilemmas faced by home-care service providers when enhancing participation among older adults receiving home care. Scandinavian Journal of Caring Sciences, 26(3), 528-536. https://doi.org/10.1111/j.1471-6712.2011.00960.x

Wollebæk, D.,\& Sivesind, K.H. (2010).Fra folkebevegese til filantropi? Frivillig innsats $i$ Norge fra 1997-2009 [From popular movement to philanthropy? Volunteering in Norway 1997-2009]. Oslo/Bergen: Senter for forskning på sivilsamfunn og frivillig sektor.

Wollebæk D and Selle P (2002) Det nye organisasjonssamfunnet: Demokrati i omforming [The new organizational society: Democracy in flux]. Bergen: Fagbokforlaget.

Wilson, A., \& Pimm, G. (1996). The tyranny of the volunteer: the care and feeding of voluntary workforces. Management Decision, 34(4), 24-40. https://doi.org/10.1108/00251749610115134

Øhrn, A. (2019). Frivillig omsorg for hjemmeboende eldre. In E. Hillestad \& J. Tjessem (Eds.), Frivillighetens kraft: organisering av frivillig innsats i eldreomsorgen. Bergen: Fagbokforlaget.

Ågotnes, G. (2016). The Institutional Practice: Dynamics of practice at nursing homes: An ethnographic study of variation in hospitalization amidst uncertainty and continuity. (PhD), University of Bergen, Bergen.

https://doi.org/10.17585/noasp.12.41 